\title{
Juice, Ethanol, and Grain Yield Potential of Five Sweet Sorghum (Sorghum bicolor [L.] Moench) Cultivars
}

\author{
Laban K. Rutto*, Yixiang Xu, Michael Brandt, Shuxin Ren, Maru K. Kering \\ Agriculture Research Station, Virginia State University, Petersburg, USA \\ Email: *1rutto@vsu.edu
}

Received February 7, 2013; revised March 7, 2013; accepted May 10, 2013

Copyright (C) 2013 Laban K. Rutto et al. This is an open access article distributed under the Creative Commons Attribution License, which permits unrestricted use, distribution, and reproduction in any medium, provided the original work is properly cited.

\begin{abstract}
Sweet sorghum (Sorghum bicolor [L.] Moench) accumulates fermentable sugars in the stem and is increasingly being studied as a potential source of feedstock for bioethanol production. The objective of this study was to evaluate biomass and grain yield in five sweet sorghum cultivars (Dale, M81E, Sugar Drip, Della and Keller) and to determine quality of extractable juice and grain. Randomized complete block experiments were performed in the summer of 2009, 2010, and 2011. Leaf dry weight varied with year and cultivar and averaged $6177 \mathrm{~kg} \cdot \mathrm{ha}^{-1}$. Fresh stem weight ranged from 21 to 54 $\mathrm{Mg} \cdot \mathrm{ha}^{-1}$ with a mean across years and cultivars of $32.9 \mathrm{Mg} \cdot \mathrm{ha}^{-1}$. Variations in stem weight were correlated with extractable juice volumes that ranged from 10 to $24 \mathrm{~m}^{3} \cdot \mathrm{ha}^{-1}$. Juice Brix values fell within a narrow range $(14 \%-19 \%)$ across years and cultivars with an average of $15.6 \%$. In all production years, theoretical sugar and ethanol yield were always numerically higher for Keller and M81E. Grain yield was lowest in Keller $\left(90 \mathrm{~kg} \cdot \mathrm{ha}^{-1}\right)$, but ranged from 400 to $1300 \mathrm{~kg} \cdot \mathrm{ha}^{-1}$ in other cultivars with a mean of $584 \mathrm{~kg} \cdot \mathrm{ha}^{-1}$ across years. However, Keller had the highest starch content with a lower proportion of resistant starch in the grain. Except for Keller, the cultivars tested are potential sources of both fermentable sugars and grain.
\end{abstract}

Keywords: Sweet Sorghum; Cultivar; Biomass; Juice and Grain Yield; Ethanol Yield Potential

\section{Introduction}

Sorghum (Sorghum bicolor [L.] Moench), a warm season tropical grass is reported to be the most widely adapted species among cereal grasses that perform favorably in dry environments [1]. Under low soil moisture conditions, sorghum maintains its physiological activity close to that of plants with sufficient moisture by increasing root length, density, and water-use efficiency [2]. Compared to other sorghums, sweet sorghum produces less grain but contains a large amount of readily fermentable sugars in the stem [3,4]. Sweet sorghums produce $23 \%$ more fermentable carbohydrates, require $37 \%$ less nitrogen fertilizer and $17 \%$ less irrigation water than maize, and could yield more ethanol than maize during a dry year [5, 6]. Sweet sorghum stem juice can be used for sugar, syrup, and ethanol production. The bagasse is also used as forage or as raw material for the paper industry [7]. Because of its efficient conversion of atmospheric $\mathrm{CO}_{2}$ into sugar, sweet sorghum is a promising crop for use in the bioenergy industry. Several characteristics make sweet sorghum suitable for bioenergy: 1) A short growth cycle

${ }^{*}$ Corresponding author. (about four months) that may allow for double cropping; 2) Easy propagation from seed; 3) Potential for fully mechanized production; 4) Dual purpose cropping for both stem sugar and grain starch; 5) High water and nutrient use efficiency; 6) Byproduct (bagasse and forage) utilization for energy production; 7) Wide adaptability to different environments $[8,9]$. Because it matures and is harvested in a single season, it has better return on a unit land area basis as compared to sugarcane $[8,10,11]$.

The use of sweet sorghum dates back over 150 years when it was used to produce concentrated syrup, forage and silage for animal feed [12]. Because of its multiple uses, sweet sorghum is cultivated in semi-arid to humid climates in about 100 countries on over 44 million hectares [13]. Although research on alternative uses of sweet sorghum has been done [14-16], it is still grown mainly for syrup, forage, and grain [15]. In the US and Europe, sweet sorghum is grown commercially for ethanol production which is blended with fossil-based fuels [17-19]. Widespread interest in sweet sorghum for ethanol is attributed to extractable stem juice rich in readily fermentable sugars $[4,11,15]$. Sweet sorghum has the potential to 
produce up to $8000 \mathrm{~L} \cdot \mathrm{ha}^{-1}$ ethanol: about twice the ethanol yield potential of corn, and $30 \%$ greater than the $6000 \mathrm{~L} \cdot \mathrm{ha}^{-1}$ average obtained from Brazilian sugarcane $[20,21]$. Also like grain sorghum, starch reserves in sweet sorghum grain can be used for ethanol production. There is need to evaluate grain starch composition in different sorghum cultivars because ethanol production efficiency from starch is a function of hydrolysis temperature, and resistant starch content in grain [22]. Determination of starch composition in sweet sorghum seed is also important because some sweet sorghum varieties may have potential as dual-purpose crops yielding both sugar-rich extractable juice and grain.

With upwards of 4000 sweet sorghum cultivars distributed throughout the world [23], there is a wide and diverse genetic base from which to develop regionally specific, highly productive cultivars. Several varieties have been tested in diverse environments to assess biomass, juice, and bioethanol productivity [24-26]. While fermentable sugar content is reported to differ with sweet sorghum variety, sucrose is the dominant sugar in all varieties $[5,10]$. The differences in sugar content and its proportional composition may be responsible for reported variations in ethanol yield among sweet sorghum cultivars $[6,19,27]$. Despite challenges including fast degradation of extracted juice, and a need for nitrogen supplementation for yeast growth $[15,28]$, sweet sorghum varieties with high biomass and juice yield hold great promise in temperate climates where sugarcane is not a viable crop. For this reason, it is important to evaluate different sweet sorghum cultivars for biomass yield and juice quality in the temperate zone. The objective of this study was to assess the agronomic performance and juice yield of five sweet sorghum cultivars (Keller, Della, Dale, M81E and Sugar Drip) as potential sources of biomass and grain for ethanol production.

\section{Materials and Methods}

\subsection{Site Characteristics, Field Preparation, and Planting}

Field experiments were performed at the Virginia State University (VSU) Randolph Research and Demonstration Farm $\left(37.1^{\circ} \mathrm{N} ; 77.3^{\circ} \mathrm{W}\right)$. The soil type at the site is a Bourne series fine sandy loam (mixed, semi-active, thermic Typic Fragiudults). Mean soil analysis values for the period of study were: $\mathrm{pH}: 6.2$, OM: $1.8 \%, \mathrm{~N}: 46 \mathrm{~kg} \cdot \mathrm{ha}^{-1}$, P: $75 \mathrm{~kg} \cdot \mathrm{ha}^{-1}, \mathrm{~K}: 278 \mathrm{~kg} \cdot \mathrm{ha}^{-1}$, Ca: $1380 \mathrm{~kg} \cdot \mathrm{ha}^{-1}$, and $\mathrm{Mg}$ : $227 \mathrm{~kg} \cdot \mathrm{ha}^{-1}$. Seasonal rainfall and temperature during the growing season in 2009, 2010, and 2011 is shown in Figure 1. Five sweet sorghum cultivars (Dale; Della; Keller; M81E; Sugar Drip) obtained from Dr. Morris Bitzer (deceased) at the University of Kentucky were planted following soybean in fields that were disked and harrowed

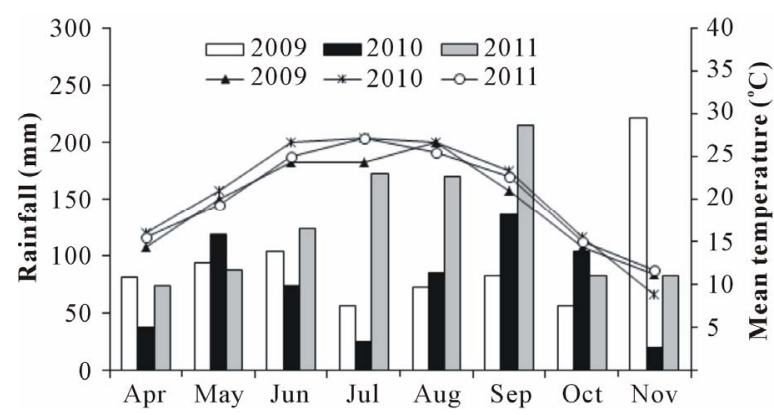

Figure 1. Seasonal rainfall (bars) and mean temperature (lines) during the 2009, 2010, and 2011 growing season.

prior to planting. Cultivars were assigned to experimental plots distributed randomly within 5 complete blocks. Each plot was planted with 4 rows each $15 \mathrm{~m}$ long with a row spacing of $75 \mathrm{~cm}$. Seeding was done at the rate of $5.4 \mathrm{~kg} \cdot \mathrm{ha}^{-1}$ on June 2, 8, and 7 in 2009, 2010, and 2011, respectively, using a seed drill set to plant at a depth of $2.5 \mathrm{~cm}$. No fertilizer was applied at planting, but all plots were top-dressed with urea at a rate of $65 \mathrm{~kg} \cdot \mathrm{ha}^{-1} \mathrm{~N}$ when sorghum plants were $30 \mathrm{~cm}$ tall. The plants were grown under rain-fed conditions and weed control was done by a combination of mechanical cultivation and hand weeding.

\subsection{Grain and Stem Harvest, and Juice Extraction}

Each cultivar was harvested after the grain reached hard dough stage $(100,104,107,115$, and 130 days after planting for Sugar Drip, Della, Dale, Keller, and M81E, respectively) by cutting and bundling plants from the two inner rows per plot. Bundles were transported to a work area where grain heads were cut and bagged, and leaves stripped from stems and weighed. Stem weight was also recorded prior to juice extraction. Stems were sub-sampled per plot and juice extracted using a portable 5-roller press (Sor-Cane Porta-Press; McClune Industries, Reynolds, GA). Juice yield per plot was recorded and brix determined using a hand-held refractometer (Atago 2522; Atago USA Inc., Bellevue, WA). Sugar content estimates were calculated based on an approach previously used by others [29] that assumes $75 \%$ of Brix as fermentable sugars. Theoretical ethanol yield $\left(\mathrm{L} \cdot \mathrm{ha}^{-1}\right)$ from extracted juice was calculated as sugar yield $\left(\mathrm{kg} \cdot \mathrm{ha}^{-1}\right)$ multiplied by a conversion factor $\left(0.581 \mathrm{~L}\right.$ ethanol $\left.(\mathrm{kg} \cdot \text { sugar })^{-1}\right)$ [30]. Grain heads were dried to moisture content below 13\% before threshing using a modified soybean thresher. Grain weight was determined per plot and a sub-sample milled to pass a $1 \mathrm{~mm}$ sieve in preparation for starch analysis. Starch analysis was done at the VSU Food Processing and Engineering lab following methods published by the American Association of Cereal Chemists (Method No. 76 - 13 for total, and No. 32 - 40 for resistant starch). 
Enzymes and basic reagents for starch analysis were purchased as Megazyme kits from Vinotec Napa (Napa, CA).

\subsection{Statistical Analysis}

Data were analyzed using the PROC MIX Procedure in SAS 9.2 (SAS Institute., Cary, NC, USA). In the model, cultivar was taken as a fixed, and replication as a random variable. When necessary, data was transformed prior to analysis. Estimates were based on the Restricted Maximum Likelihood.

\section{Results}

\subsection{Sweet Sorghum Leaf and Stem Biomass at Harvest}

In all three years, M81E produced the largest $(P<0.05)$ amount of leaf biomass (Table 1). In 2009, all cultivars, other than M81E which produced $6553 \mathrm{~kg} \cdot \mathrm{ha}^{-1}$ of leaf biomass ( $45 \%$ more), had similar leaf biomass averaging $4515 \mathrm{~kg} \cdot \mathrm{ha}^{-1}$. In 2010, M81E produced $16,820 \mathrm{~kg} \cdot \mathrm{ha}^{-1}$ of leaf, about twice as much as that produced by Dale, Della, and Keller and a 5-fold increase compared to Sugar Drip. In 2011, M81E and Della had 10,398 and $7856 \mathrm{~kg} \cdot \mathrm{ha}^{-1}$ of leaf, respectively. Other varieties produced similar quantities of leaf biomass ranging from 5786 to $6800 \mathrm{~kg} \cdot \mathrm{ha}^{-1}$.

In 2009 , all cultivars had similar $(P<0.05)$ quantities of fresh stem biomass ranging from 25.8 to $29.9 \mathrm{Mg} \cdot \mathrm{ha}^{-1}$ (Table 1). In 2010, Sugar Drip recorded the lowest amount of fresh stem biomass $\left(20.9 \mathrm{Mg} \cdot \mathrm{ha}^{-1}\right)$ while yield in other cultivars was similar averaging 49.8 tons $\cdot \mathrm{ha}^{-1}$. Fresh stem biomass was highest $(P<0.05)$ in Keller $\left(51.0 \mathrm{Mg} \cdot \mathrm{ha}^{-1}\right)$ and lowest in Sugar Drip $\left(26.4 \mathrm{Mg} \cdot \mathrm{ha}^{-1}\right)$ in 2011. Although M81E stem fresh weight was comparable to that of Keller, it was significantly higher $(P<$ $0.05)$ than that of Dale.

\subsection{Extractable Juice, Brix, and Theoretical Sugar and Ethanol Yield}

The amount of juice extracted from fresh stems in 2009 was similar $(P<0.01)$ for all sweet sorghum cultivars and averaged $11.6 \mathrm{~m}^{3} \cdot \mathrm{ha}^{-1}$ (Table 2). The extracted juice also had similar $(P<0.05)$ Brix values $(15.5 \%)$. However, for 2010 and 2011, the juice volume and Brix were affected by variety $(P<0.05)$, and juice was followed a similar trend. In 2010, juice from Sugar Drip $\left(7.6 \mathrm{~m}^{3} \cdot \mathrm{ha}^{-1}\right)$ was significantly lower $(P<0.05)$ than that produced by other varieties. During 2010, Keller, Dale and Della had statistically $(P<0.05)$ similar juice yields averaging 18.5 $\mathrm{m}^{3} \cdot \mathrm{ha}^{-1}$, but juice yield in Dale was similar to the 23.4 $\mathrm{m}^{3} \cdot \mathrm{ha}^{-1}$ produced by M81E. In 2010, the highest and lowest juice Brix was obtained in Keller and M81E, respectively. Like 2010, extractable juice and juice Brix
Table 1. Sweet sorghum biomass (leaf and stem) yield as affected by year and cultivar in five sweet sorghum (Sorghum bicolor) cultivars.

\begin{tabular}{|c|c|c|c|}
\hline \multirow{2}{*}{ Variety } & 2009 & 2010 & 2011 \\
\hline & \multicolumn{3}{|c|}{ Leaf dry matter $\left(\mathrm{kg} \cdot \mathrm{ha}^{-1}\right)$} \\
\hline M81E & $6553 a^{z}$ & $16,830 \mathrm{a}$ & $10,398 \mathrm{a}$ \\
\hline Sugar Drip & $4314 \mathrm{~b}$ & $3640 \mathrm{c}$ & $5786 \mathrm{c}$ \\
\hline Keller & $4574 \mathrm{~b}$ & $8549 \mathrm{~b}$ & $6803 \mathrm{bc}$ \\
\hline Dale & $4835 \mathrm{~b}$ & $8865 \mathrm{~b}$ & $6001 \mathrm{c}$ \\
\hline \multirow[t]{2}{*}{ Della } & $4337 \mathrm{~b}$ & $8563 \mathrm{~b}$ & $7856 \mathrm{~b}$ \\
\hline & \multicolumn{3}{|c|}{ 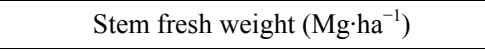 } \\
\hline M81E & $29.9 \mathrm{a}$ & $53.8 \mathrm{a}$ & $45.4 \mathrm{ab}$ \\
\hline Sugar Drip & $25.8 \mathrm{a}$ & $20.9 \mathrm{~b}$ & $26.4 \mathrm{~d}$ \\
\hline Keller & $26.7 \mathrm{a}$ & $49.0 \mathrm{a}$ & $51.0 \mathrm{a}$ \\
\hline Dale & $26.9 \mathrm{a}$ & $47.8 \mathrm{a}$ & $32.0 \mathrm{~cd}$ \\
\hline Della & $27.8 \mathrm{a}$ & $48.6 \mathrm{a}$ & $38.5 \mathrm{bc}$ \\
\hline
\end{tabular}

${ }^{\mathrm{z}}$ Means within columns followed by the same letter(s) are not significantly different $(P \leq 0.05)$.

Table 2. Extractable juice, brix, and theoretical sugar and ethanol yield as affected by year and cultivar in five sweet sorghum (Sorghum bicolor) cultivars.

\begin{tabular}{|c|c|c|c|}
\hline \multirow{2}{*}{ Variety } & 2009 & 2010 & 2011 \\
\hline & \multicolumn{3}{|c|}{ Juice $\left(\mathrm{m}^{3} \cdot \mathrm{ha}^{-1}\right)$} \\
\hline M81E & $12.9 \mathrm{a}^{\mathrm{z}}$ & $23.4 \mathrm{a}$ & $17.0 \mathrm{ab}$ \\
\hline Sugar Drip & $9.7 \mathrm{a}$ & $7.6 \mathrm{c}$ & $9.6 \mathrm{c}$ \\
\hline Keller & $12.2 \mathrm{a}$ & $17.0 \mathrm{~b}$ & $18.9 \mathrm{a}$ \\
\hline Dale & $12.0 \mathrm{a}$ & $21.1 \mathrm{ab}$ & $12.6 \mathrm{bc}$ \\
\hline \multirow[t]{2}{*}{ Della } & $10.9 \mathrm{a}$ & $18.2 \mathrm{~b}$ & $15.7 \mathrm{ab}$ \\
\hline & \multicolumn{3}{|c|}{ Brix (\%) } \\
\hline M81E & $15.9 \mathrm{a}$ & $13.9 \mathrm{c}$ & $17.1 \mathrm{ab}$ \\
\hline Sugar Drip & $16.1 \mathrm{a}$ & $16.1 \mathrm{bc}$ & $16.3 \mathrm{ab}$ \\
\hline Keller & $15.5 \mathrm{a}$ & $18.5 \mathrm{a}$ & $18.4 \mathrm{a}$ \\
\hline Dale & $14.3 \mathrm{a}$ & $14.3 \mathrm{bc}$ & $18.7 \mathrm{a}$ \\
\hline \multirow[t]{2}{*}{ Della } & $15.7 \mathrm{a}$ & $16.2 \mathrm{~b}$ & $14.0 \mathrm{~b}$ \\
\hline & \multicolumn{3}{|c|}{ Sugar $\left(\mathrm{kg} \cdot \mathrm{ha}^{-1}\right)$} \\
\hline M81E & $1537 \mathrm{a}$ & 2443 a & $2181 \mathrm{ab}$ \\
\hline Sugar Drip & 1189 a & $916 \mathrm{~b}$ & $1212 \mathrm{c}$ \\
\hline Keller & 1427 a & 2349 a & $2658 \mathrm{a}$ \\
\hline Dale & $1282 \mathrm{a}$ & $2291 \mathrm{a}$ & $1730 \mathrm{bc}$ \\
\hline \multirow[t]{2}{*}{ Della } & $1291 \mathrm{a}$ & $2204 \mathrm{a}$ & $1756 \mathrm{bc}$ \\
\hline & \multicolumn{3}{|c|}{ Ethanol yield $\left(\mathrm{L} \cdot \mathrm{ha}{ }^{-1}\right)$} \\
\hline M81E & $893 \mathrm{a}$ & 1419 a & $1267 \mathrm{ab}$ \\
\hline Sugar Drip & $691 \mathrm{a}$ & $532 \mathrm{~b}$ & $704 \mathrm{c}$ \\
\hline Keller & 829 a & $1365 \mathrm{a}$ & $1544 \mathrm{a}$ \\
\hline Dale & $745 \mathrm{a}$ & $1331 \mathrm{a}$ & $1005 \mathrm{bc}$ \\
\hline Della & $750 \mathrm{a}$ & $1281 \mathrm{a}$ & $1020 \mathrm{bc}$ \\
\hline
\end{tabular}

${ }^{\mathrm{z}}$ Means within columns followed by the same letter(s) are not significantly different $(P \leq 0.05)$. 
values significantly differed $(P<0.05)$ with variety in 2011 (Table 2). Keller, M81E, and Della had similar juice yields averaging $17.4 \mathrm{~m}^{3} \cdot \mathrm{ha}^{-1}$. In 2011, juice yield $\left(12.6 \mathrm{~m}^{3} \cdot \mathrm{ha}^{-1}\right)$ from Dale was not significantly different $(P<0.05)$ from that produced by M81E $\left(17.0 \mathrm{~m}^{3} \cdot \mathrm{ha}^{-1}\right)$ and Della $\left(15.7 \mathrm{~m}^{3} \cdot \mathrm{ha}^{-1}\right)$. The lowest amount of juice $(9.6$ $\left.\mathrm{m}^{3} \cdot \mathrm{ha}^{-1}\right)$ produced by Sugar Drip was similar $(P<0.05)$ to that of Dale. Juice extracted from Keller and Dale had higher $(P<0.05)$ Brix values than from Della. M81E and Sugar Drip had similar $(P<0.05)$, but numerically lower Brix values compared with Dale and Keller, and similar but numerically higher values than Della. Extractable juice was correlated with the quantity of fresh stem weight for all cultivars (data not shown).

Similar to extracted juice, theoretical sugar and ethanol yield was similar $(P<0.05)$ among cultivars in 2009, averaging $1345 \mathrm{~kg} \cdot \mathrm{ha}^{-1}$ and $781 \mathrm{~L} \cdot \mathrm{ha}^{-1}$, respectively (Table 2). In 2010, sugar and ethanol yield from Sugar Drip was more than $50 \%$ lower than in the other cultivars, while in 2011, Keller produced the highest juice (2658 $\left.\mathrm{kg} \cdot \mathrm{ha}^{-1}\right)$ and ethanol $\left(1544 \mathrm{~L} \cdot \mathrm{ha}^{-1}\right)$ and Sugar Drip the lowest $\left(1212 \mathrm{~kg} \cdot \mathrm{ha}^{-1}\right)$ and $704\left(\mathrm{~L} \cdot \mathrm{ha}^{-1}\right)$, respectively.

\subsection{Grain Yield and Grain Starch Composition}

In 2009 , grain yield was affected by variety $(P<0.01)$ and was highest in Dale and Della averaging 1468 and $1240 \mathrm{~kg} \cdot \mathrm{ha}^{-1}$, respectively (Table 3 ). Keller which produced $67 \mathrm{~kg} \cdot \mathrm{ha}^{-1}$ was the lowest $(P<0.01)$ yielding cultivar followed by Sugar Drip. In 2010, Dale and Sugar Drip produced the highest yields averaging $1150 \mathrm{~kg} \cdot \mathrm{ha}^{-1}$, followed by Della $\left(933 \mathrm{~kg} \cdot \mathrm{ha}^{-1}\right)$, while Keller produced the least. In 2011, M81E produced higher yield (708 $\left.\mathrm{kg} \cdot \mathrm{ha}^{-1}\right)$, than Dale and Keller, but similar $(P<0.05)$ to that of Sugar Drip and Della. Due to the snapped panicles and lodging after Hurricane Irene, grain yield dropped by between $25 \%$ and $80 \%$ in 2011 compared to the first two years of production in Dale, Della, and M81E.

Total and resistant starch in sweet sorghum grain differed with species with Keller recording the highest (555 $\mathrm{g} \cdot \mathrm{kg}^{-1}$ ) total starch as a portion of grain dry weight (Figure 2). M81E averaged $388 \mathrm{~g} \cdot \mathrm{kg}^{-1}$ total starch while Sugar Drip and Della had similar averages $\left(330 \mathrm{~g} \cdot \mathrm{kg}^{-1}\right)$. Dale had the lowest values at $272 \mathrm{~g} \cdot \mathrm{kg}^{-1}$. Of total starch, the proportion of resistant starch was highest in M81E $(83 \%)$ followed by Dale (82\%), Sugar Drip (82\%) and Della (76\%), and represented 322, 224, 267, and 255 $\mathrm{g} \cdot \mathrm{kg}^{-1}$, respectively. Resistant starch content was lowest in Keller (32\%) at $176 \mathrm{~g} \cdot \mathrm{kg}^{-1}$.

\section{Discussion}

Fresh aboveground biomass and juice Brix values from the current study were comparable to those reported in Alabama [31]. Fresh stalk yield for Keller and M81E was
Table 3. Grain yield from five sweet sorghum (Sorghum bicolor) cultivars in 2009, 2010, and 2011.

\begin{tabular}{cccc}
\hline \multirow{2}{*}{ Variety } & \multicolumn{3}{c}{ Grain yield $\left(\mathrm{kg} \cdot \mathrm{ha}^{-1}\right)$} \\
\cline { 2 - 4 } & $\mathbf{2 0 0 9}$ & $\mathbf{2 0 1 0}$ & $\mathbf{2 0 1 1}$ \\
\hline M81E & $1208 \mathrm{~b}^{\mathrm{z}}$ & $958 \mathrm{ab}$ & $708 \mathrm{a}$ \\
Sugar Drip & $462 \mathrm{c}$ & $1351 \mathrm{a}$ & $484 \mathrm{ab}$ \\
Keller & $67 \mathrm{~d}$ & $105 \mathrm{c}$ & $108 \mathrm{c}$ \\
Dale & $1468 \mathrm{a}$ & $933 \mathrm{ab}$ & $249 \mathrm{bc}$ \\
Della & $1240 \mathrm{ab}$ & $765 \mathrm{~b}$ & $436 \mathrm{abc}$ \\
\hline
\end{tabular}

${ }^{\mathrm{z}}$ Means within columns followed by the same letter(s) are not significantly different $(P \leq 0.05)$.

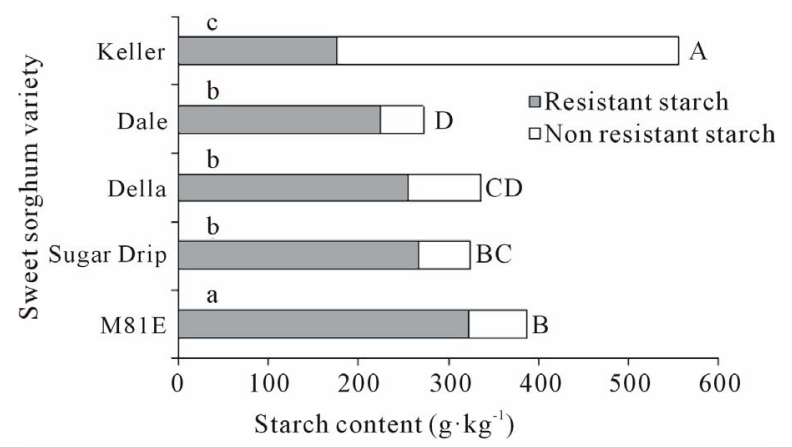

Figure 2. Starch content and distribution in grain from five sweet sorghum (Sorghum bicolor) cultivars. Comparisons ( $P$ $<0.05$ ) are presented for resistant (lower case letters) and total (resistant + non-resistant) starch (upper case letters).

comparable to those reported in Nebraska [29].

Though extracted juice for Della and M81E in 2010 reached levels similar to those reported in western Texas [32], M81E juice content was lower than the 30.0 $\mathrm{Mg} \cdot \mathrm{ha}^{-1}$ reported in Kansas [33]. Compared to other production years, the low stem and leave weights observed in 2009 could be attributed to the relatively low rainfall amounts in late summer. Compared to 2010, the low extractable juice in M81E, Keller, Dale, and Della in 2009 and M81E, Dale, and Della in 2011 was due to low fresh stem yield. Similarly, annual differences in fresh stem yield resulted in the observed differences in sugar and potential ethanol yields. Sugar Drip low sugar and potential ethanol yield may be due mainly to its low fresh stem yields because it showed Brix values comparable to other cultivars. The differences in ethanol yield between this study and others could be due to juice volume which may depend on juice extraction efficiency.

Low grain yield in Keller was mainly due to bird destruction. The low resistant starch content could be a positive palatability attribute that drove birds to preferentially feed on Keller seed earlier and for a much longer period than other varieties. Though not determined, sweet sorghum cultivars with a lower proportion of resistant starch as in Keller may be easily digested by birds. Differences in the proportion and type of starch in the grain 
among cultivars tested may allow for targeted production of dual purpose sorghums. For example, owing to a high level of non-resistant starch, Keller could be cropped as a source of both fermentable sugars and grain starch for ethanol production since non-resistant starch can be easily degraded by amylases leading to the release of simple sugars that can be fermented to ethanol. On the other hand, resistant starch has been found to reduce the efficiency of ethanol production by increasing fermentation time [34]. Therefore, grain from varieties like Dale, Della, M81E and Sugar Drip with high levels of resistant starch may be sold to the food industry as raw material for manufacture of non-digestible starch. Resistant starch has been reported to decrease carbohydrate absorption in humans and to be a substrate for colon bacteria that release short chain fatty acids shown to lower colon $\mathrm{pH}$ and to help reduce incidences of obesity, colon cancer and colon inflammatory diseases [35-37].

\section{Conclusion}

The study affirms other findings showing sweet sorghum potential for bioethanol production. However, variation in potential ethanol yields between production years for the same cultivar may indicate the strong effect of prevailing weather conditions during/or close to harvest time on extractable juice volumes. Also this study has shown that despite the relatively lower grain yield, sweet sorghum may hold potential for simultaneous production of fermentable carbohydrates in juice and grain. The observed differences in grain starch composition shows the potential for selection of cultivars with high non-resistant starch that could be grown for both grain and juice for ethanol production. More research is also needed on tools for mechanical harvesting of both seed and fresh stems in a single pass. Development of such equipment, combined with sweet sorghum production systems that optimize seed and juice production may facilitate large-scale production of sweet sorghum for bioenergy.

\section{Acknowledgements}

We are grateful to Messrs. Robert Kraemer and Landon West, VSU Farm Manager and Assistant Farm Manager, respectively, for field support, and to Dr. Edward Sismour (VSU Food Processing and Engineering) for assistance with starch analysis.

This is a contribution of Virginia State University Agriculture Research Station Journal Article No. 302.

\section{REFERENCES}

[1] F. M. Hons, R. F. Moresco, R. P. Wiedenfeld and J. T. Cothren, "Applied Nitrogen and Phosphorus Effects on Yield and Nutrient Uptake by High Energy Sorghum Produced for Grain and Biomass," Agronomy Journal, Vol.
76, 1986, pp. 1069-1078. doi:10.2134/agronj1986.00021962007800060026x

[2] W. Zegada-Lizarazu, A. Zatta and A. Monti, "Water Uptake Efficiency and Above- and Below-Ground Biomass Development of Sweet Sorghum and Maize under Different Water Regimes," Plant Soil, Vol. 351, No. 1-2, 2012, pp. 47-60. doi:10.1007/s11104-011-0928-2

[3] P. L. Maskand and W. C. Morris, "Sweet Sorghum Culture and Syrup Production," ACES Publications Alabama Co-Operative Extension Publications, 1991, pp. 1-12

[4] A. S. Bennett and R. P. Anex, "Production, Transportation and Milling Costs of Sweet Sorghum as a Feedstock for Centralized Bioethanol Production in the Upper Midwest," Bioresource Technology, Vol. 100, No. 4, 2009, pp. 1595-1607. doi:10.1016/j.biortech.2008.09.023

[5] F. J. Hills, R. T. Lewellen and I. O. Skoyen, "Sweet Sorghum Cultivars for Alcohol Production," California Agriculture, Vol. 44, No. 1, 1990, pp. 14-16.

[6] D. H. Putnam, W. E. Lueschen, B. K. Kanne and T. R. Hoverstad, "A Comparison of Sweet Sorghum Cultivars and Maize for Ethanol Production," Journal of Production Agriculture, Vol. 4, No. 3, 1991, pp. 377-381. doi:10.2134/jpa1991.0377

[7] S. Koeppen, G. Reinhardt and S. Gaertner, "Assessment of Energy and Greenhouse Gas Inventories of Sweet Sorghum for First and Second Generation Bioethanol," FAO Environmental and Natural Resources Service Series, No. 30, FAO, Rome, 2009.

[8] B. V. S. Reddy, S. Ramesh, P. S. Reddy, B. Ramaiah, P. M. Salimath and K. Rajashekar, "Sweet Sorghum-A Potential Alternate Raw Material for Bio-Ethanol and Bioenergy," International Sorghum and Millets Newsletter, Vol. 46, 2005, pp. 79-86.

[9] J. Fernandez and M. D. Curt, "New Energy Crops for Bioethanol Production in the Mediterranean Region," International Sugar Journal, Vol. 107, No. 1283, 2005, pp. 622-627.

[10] G. Grassi, "Sweet Sorghum: One of the Best World FoodFeed-Energy Crops," LANMET, 2001.

[11] S. Prasad, A. Singh, N. Jainand and H. C. Joshi, "Ethanol Production from Sweet Sorghum Syrup for Utilization as Automotive Fuel in India," Energy Fuels, Vol. 21, No. 4, 2007, pp. 2415-2420. doi:10.1021/ef060328z

[12] R. E. Schaffert, "Sweet Sorghum Substrate for Industrial Alcohol," Proceedings of the International Workshop on Policy, Practice, and Potential Relating to Uses of Sorghum and Millets, Bulawayo, 1988, p. 26.

[13] M. Sakellariou-Makrantonaki, D. Papalexis, N. Nakos and I. K. Kalavrouziotis, "Effect of Modern Irrigation Methods on Growth and Energy Production of Sweet Sorghum (var. Keller) on a Dry Year in Central Greece," Agricultural Water Management, Vol. 90, No. 3, 2007, pp. 181-189. doi:10.1016/j.agwat.2007.03.004

[14] J. R. N. Taylor, T. J. Schober and S. R. Bean, "Novel Food and Non-Food Uses for Sorghum and Millets," Journal of Cereal Science, Vol. 44, No. 3, 2006, pp. 252-271. doi:10.1016/j.jcs.2006.06.009

[15] E. Gnansounou, A. Dauriat and C. E. Wyman, "Refining 
Sweet Sorghum to Ethanol and Sugar: Economic TradeOffs in the Context of North China," Bioresource Technology, Vol. 96, No. 9, 2005, pp. 985-1002. doi:10.1016/j.biortech.2004.09.015

[16] M. A. Liebig and G. E. Varvel, "Effects of Western Corn Belt Cropping Systems on Agroecosystem Function," Agronomy Journal, Vol. 95, No. 2, 2003, pp. 316-322. doi:10.2134/agronj2003.0316

[17] R. E. Schaffert and L. M. Gourley, "Sorghum as an Energy Source," Proceedings of the International Symposium on Sorghum, Patancheru, 1981, pp. 605-623.

[18] C. O. Kangama and X. Rumei, "Introduction of Sorghum (Sorghum bicolor (L.) Moench) into China," African Journal of Biotechnology, Vol. 4, No. 7, 2005, pp. 575579.

[19] Y. L. Zhao, A. Dolat, Y. Steinberger, X. Wang, A. Osman and G. H. Xie, "Biomass Yield and Chemical Composition of Sweet Sorghum Cultivars Grown for Biofuel," Crop Science, Vol. 111, No. 1-2, 2009, pp. 55-64.

[20] E. L. Hunter and I. C. Anderson, "Sweet Sorghum," In J. Janick, Ed., Horticultural Reviews, John Wileys \& Sons, Inc., Oxford, 1997, Vol. 21, pp. 73-104.

[21] D. Luhnow and G. Samor, "As Brazil Fill up on Ethanol, It Weans off Energy Imports,” 2006. http://wsj.com/article/SB1 13676947533241219.html

[22] V. Sharma, K. D. Rausch, J. V. Graeber, S. J. Schmidt, P. Buriak, M. E. Tumbleson and V. Singh, "Effect of Resistant Starch on Hydrolysis and Fermentation of Corn Starch for Ethanol," Applied Biochemistry and Biotechnology, Vol. 160, No. 3, 2005, pp. 800-811. doi:10.1007/s12010-009-8651-7

[23] G. Grassi, G. Tondi and P. Helm, "Small-Sized Commercial Bioenergy Technologies as an Instrument of Rural Development," Biomass and Agriculture: Sustainability, Markets and Policies, OECD Publication Service, Paris, 2004, pp. 277-287.

[24] F. J. Davila-Gomeza, C. Chuck-Hernandeza, E. Perez-Carrilloa, W. L. Rooney and S. O. Serna-Saldivara, "Evaluation of Bioethanol Production from Five Different Varieties of Sweet and Forage Sorghums (Sorghum bicolor (L) Moench)," Industrial Crops and Products, Vol. 33, No. 3, 2011, pp. 611-616. doi:10.1016/j.indcrop.2010.12.022

[25] M. Guigoi, C. Lareo, L. V. Pérez, M. E. Lluberas, D. Vázquez and M. D. Ferrari, "Bioethanol Production from Sweet Sorghum: Evaluation of Post-Harvest Treatments on Sugar Extraction and Fermentation," Biomass and Bioenergy, Vol. 35, No. 7, 2011, pp. 3058-3062. doi:10.1016/j.biombioe.2011.04.028

[26] L. Laopaiboon, P. Thanonkeo, S. Naunpeng, P. Jaisil and P. Laopaiboon, "Ethanol Production from Sweet Sorghum Juice in Batch and Fed-Batch Fermentations by
Saccharomyces cerevisiae TISTR 5048," In: Technology and Innovation for Sustainable Development Conference (TISD 2006), Khon Kaen University, 2006, pp. 389-391.

[27] T. W. Pfeiffer, M. J. Bitzer, J. J. Toy and J. F. Pedersen, "Heterosis in Sweet Sorghum and Selection of a New Sweet Sorghum Hybrid for Use in Syrup Production in Appalachia," Crop Science, Vol. 50, No. 5, 2010, pp. 1788-1794. doi:10.2135/cropsci2009.09.0475

[28] X. Wu, S. Staggenborg, J. L. Propheter, W. L. Rooney, J. $\mathrm{Yu}$ and D. Wang, "Features of Sweet Sorghum Juice and Their Performance in Ethanol Fermentation," Industrial Crop Production, Vol. 31, No. 1, 2010, pp. 164-170. doi:10.1016/j.indcrop.2009.10.006

[29] C. S. Wortmann, A. J. Liska, R. B. Ferguson, D. J. Lyon, R. N. Klein and I. Dweikat, "Dryland Performance of Sweet Sorghum and Grain Crops for Biofuel in Nebraska," Agronomy Journal, Vol. 102, No. 1, 2010, pp. 319326. doi:10.2134/agronj2009.0271

[30] V. H. Teetor, D. V. Duclos, E. T. Wittenberg, K. M. Young, J. Chawhuaymak, M. R. Riley and D. T. Ray, "Effects of Planting Date on Sugar and Ethanol Yield of Sweet Sorghum Grown in Arizona," Industrial Crops and Products, Vol. 34, No. 2, 2011, pp. 1293-1300. doi:10.1016/j.indcrop.2010.09.010

[31] J. M. Soileau and B. N. Bradford, "Biomass and Sugar Yield Response of Sweet Sorghum to Lime and Fertilizer," Agronomy Journal, Vol. 77, 1985, pp. 471-475. doi:10.2134/agronj1985.00021962007700030025x

[32] P. L. Tamang, K. F. Bronson, A. Malapati, R. Schwartz, J. Johnson and J. Moore-Kucera, "Nitrogen Requirement for Ethanol Production from Sweet and Photoperiod Sensitive Sorghums in the Southern High Plains," Agronomy Journal, Vol. 103, No. 2, 2011, pp. 431-440.

[33] J. L. Propheter and S. Straggenborg, "Performance of Annual and Perennial Biofuel Crops. Yield during the First Two Years," Agronomy Journal, Vol. 102, No. 2, 2010, pp. 806-814. doi:10.2134/agronj2009.0301

[34] D. Wong, "Sorghum Starch for Biofuels," International Conference on Sorghum for Biofuel, Houston, 2008. http://www.ars.usda.gov/meetings/Sorghum/presentations /Wang\%202008\%20Houston\%20V1.pdf

[35] K. I. Baghurst, P. A. Baghurst and S. J. Record, "Dietary Fiber, Non-Starch Polysaccharides and Resistant Starch," In: G. A. Spiller, Ed., CRC Handbook of Dietary Fiber in Human Health, CRC Press, Boca Raton, 1996, pp. 583591.

[36] A. Dilek, "The Effects of Sorghum (Sorghum bicolor (L.) Moench) Phenolic Compounds on Starch Digestibility of Porridges," Ph.D. Dissertation, A \& M University, 2008.

[37] S. Hendrich, "Battling Obesity with Resistant Starch," Food Technology, Vol. 64, No. 3, 2010, pp. 22-30. 